\begin{abstract}
報
る Packard 社の液体シンチレーションカウンターを 用いました。この際同所所長千谷利三氏, 第 2 部長飯 塚義助氏, 及び池田研究員の協力と助言を得ました。 又多数のガラス電解槽の製作，水菜発生装置の組立等 ガラス関係の仕事はすべて睍在武蔵工業大学ガラス研 究窂主任吉波重焳氏の手を煩わしました。 $\beta / \alpha$ の測定 䒠験注武藏工業大学原子力研觉所の小山正希氏の大 きな協力を得ました。この 8 氏に厚く感謝の意を表し ます。

又この研究には昭和32,3年の文部省科学研究热の援 助を受けましたので関係者各位に感謝致します。

\section{REFERENCES}

1) W.F. Libby: Phys. Rev. 69, 671 (1946).

2) A.T.Wilson and G.J. Fergusson: Geochim. cosmochim. Acta 18, 273 (1960).

3) E.L. Firemna: Phys. Rev. 91, 922 (1953).

4) Sheldon Kaufman and W. F. Libby: Phys. Rev. 93, 1337 (1954).

5) E. L. Fireman and D. Schwarzer: Phys. Rev. 94, 385 (1954).

6) A.V. Grosse: Science 113, 1 (1951).

7) F. Begemann: 1958 Proc. of the Inter. Conf. on the Peaceful Uses of Atomic Energy
質苗分析

$\mathrm{P} / 1963$.

8) W.F. Libby: Proc. Nat. Acad. Sci. 44, 818 (1958).

9) W.F. Libby: Proc. Nat. Acad. Sci. 45,, 973 (1959).

10) J.R. Gat: Annual Program Report No. 3 TID-11879.

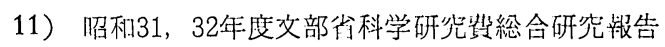
集録 放射線編 P.10, 11西脇, 河合: 三重水秦 の测定法の研劣

12）千谷利三: 重水素々重水裳華庰

13) Ernst Schumacher: Helvetica Chimica Acta 18, 1019 (1960).

14）千谷, 堀部, 小早川: 質量分析 6, 27 (Mar. 1956).

15）トレーサー技術; 実験化学講座 13卷 P.88 丸善

16) Packard Operational Manual (of Liquid Scintillation Spectrometer, model $314 \mathrm{X}$ )

17) R.R. Foster, D.H. Purcell and J.A. Wheat: AEC Research and Development Report, DP558 (1961).

18）浜田, 姜, 高橋: 1961年度理化学研究所学術講 演会予稿集 p.58 
No. 21, October. 1962

\title{
Relative Measurements of Lithium Isotope Ratio by Surface Ionization Ion Source I. Laboratory Standard Lithium Sulfate (Merck)
}

\author{
Setsuo Taniguchi, ${ }^{*}$ Osamu Toyama* and Teruo Hayakawa*
}

(Received July 20, 1962)

\begin{abstract}
Relative measurements of lithium isotope ratio for lithium sulfate (Merck) have been made by using a surface ionization ion source of the triple filament type. The isotope ratio obtained by the measured point method is $\left({ }^{7} \mathrm{Li} /{ }^{6} \mathrm{Li}\right)_{\mathrm{M} . \mathrm{P}}=12.38 \pm 0.03$ and fairly coincides with the isotope ratio $\left({ }^{7} \mathrm{Li} /{ }^{6} \mathrm{Li}\right)_{\mathrm{I} . \mathrm{I}}=12.39 \pm 0.01$ by the ion current integration method. The distribution of the isotope ratios obtained by the measured point method with time is normal. The measurable isotope fractionation over the lifetime of sample evaporation is not found. The background ions emitted from the tungsten filament are also examined and their behaviours are discussed.
\end{abstract}

\section{Introduction}

Terrestrial lithium comprises two kinds of the stable isotopes of mass numbers 6 and 7. The mass spectroscopic relative measurements of the isotope ratios of lithium for metals, terrestrial minerals and chemical reagents were carried out by many investigators ${ }^{1-9}$, but the results obtained for various lithium samples and by different types of the ion source are widely variant. The marked distribution of these results of the relative measurements may be attributed to the following different kinds of sources.

One of them comes from the true variations in the isotope ratio among various lithium minerals of different geological origins and lithium reagents prepared from them. Since the isotope fractionation of lithium under various physical changes and chemical reactions has been expected to be noticeable ${ }^{10-12)}$, the isotopic composition of lithium may be significantly variant among different terrestrial minerals and one can expect the significant difference in the distribution of lithium isotopes even in the same mineral of particular geological origins. The others imply the apparent variation in the lithium isotope ratio peculiar to the method of measurements.** When relative measurements are worked out by an ion source of the furnace-electron impact type, the fractionation of the lithium isotopes under migration and evaporation of lithium atoms and various molecular species is inevitable. In this case it seems difficult to find the best fitted method of correction for the isotope fractionation effects, unless metallic lithium of known isotopic composition is used as the standard sample and the ion currents $\left({ }^{6} \mathrm{Li}^{+}\right.$and $\left.{ }^{7} \mathrm{Li}^{+}\right)$are integrated until exhaustion of them.

For the relative measurements by an ion source of the single filament type, owing to the fact that the mechanism of ionization accompanied with diffusion, lateral migration and evaporation is fairly complicated, the correction for the isotope fractionation under these processes is considerably difficult. The isotope fractionation of lithium under lateral migration and evaporation is

* Department of Chemistry and Department of Applied Chemistry, University of Osaka Prefecture, Mozu-umemachi, Sakai

** Systematic errors due to the mass discrimination effect proper to each mass spectrometer are usually in minor order of the magnitude and beside the question of the relative measurements. 
also unavoidable for the measurements by an ion source of the triple filament type, but the process of ionization seems fairly simpler than that for the ion source of the single filament type. For this type of the ion source, the isotope fractionation by lateral migration can be diminished by adequate designing of the shape of the sample filaments and the isotope fractionation by evaporation can also be greatly restricted by the selection of proper lithium samples and proper adjustment of temperatures of the sample filaments. By elevation of temperatures of the center filament it is possible to increase the ion intensities and diminish the isotope fractionation by ionization, if there is, but it will be the best correction of the isotope fractionation to integrate the ion currents ${ }^{6} \mathrm{Li}^{+}$and ${ }^{7} \mathrm{Li}^{+}$ until exhaustion of them by the stepwise elevation of temperatures of the sample filaments.

In recent years, the present authors have worked on the relative measurements of the isotope ratio of lithium in terrestrial minerals and on microanalysis of lithium by the isotope dilution method. This paper reports the relative measurements of the lithium isotope ratio for lithium sulfate of the Merck reagent preferred as the laboratory standard material.

\section{Experimental}

\subsection{Samples}

Lithium sulfate monohydrate $\mathrm{Li}_{2} \mathrm{SO}_{4} \cdot \mathrm{H}_{2} \mathrm{O}$ (E. Merck A.G.) was used as the laboratory standard and no further purification was processed. The standard stock solution of $6.38 \mathrm{mg}$ of lithium per $\mathrm{ml}$ of the solution was prepared by dissolving $11.5 \mathrm{~g}$ of lithium sulfate monohydrate (E. Merck A.G.) in $200 \mathrm{ml}$ of carefully re-distilled water.

For the benefit of measurements, three kinds of the sample solutions which contain $3.19,1.28$ and $0.64 \mathrm{mg}$ of lithium per $\mathrm{ml}$ of respective solution were prepared from three aliquots of the stock solution by dilution with re-distilled water. In order to avoid lithium contamination these sample solutions were all stored in polyethylene bottles.

\subsection{Mass Spectrometer}

The mass spectrometer used is a $90^{\circ}$ direction focusing type with single ion collector and 135 $\mathrm{mm}$ radius of the analyzer tube, and magnetic scanning was used for ion selection. A surface ionization ion source of the triple filament type used in the present work is schematically shown in Fig. 1, and the slit widths and potential arrangement of the electrodes are listed in Table 1. Tungsten rib-

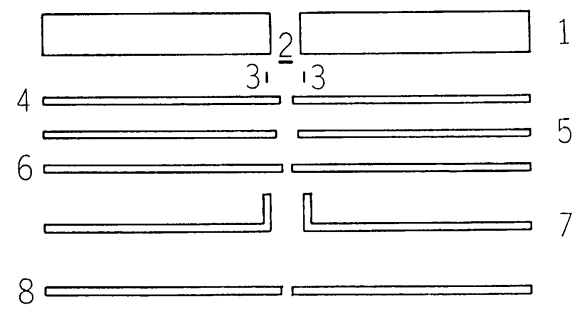

Fig. 1. Schematic diagram of the suface ionization ion source of the triple filan:ent type.
1: Guard plate,
2: Center filament,
3: Sample filament,
4: Ion accelerating plate,
5: Lens plate,
6: Defining plate,
7: Ion deflecting plate, 8 : Buffer plate.

* Chemical atomic weight of lithi'xm in the laboratory standard lithium sulfate monohydrate (E. Merck A.G.) was provided as 6.940 . 
Table 1. Slit widths and potential arrangement of the electrodes.

\begin{tabular}{c|c|c}
\hline $\begin{array}{c}\text { Plates and } \\
\text { filaments }\end{array}$ & $\begin{array}{c}\text { Slit widths } \\
(\mathrm{mm})\end{array}$ & $\begin{array}{c}\text { Electrode potentials } \\
(\mathrm{V})\end{array}$ \\
\hline 1 & - & 1105 \\
2 & - & 1105 \\
3 & - & 1105 \\
4 & $0.75 \times 10$ & 1100 \\
5 & $1.50 \times 10$ & 1010 \\
6 & $0.25 \times 10$ & earth \\
7 & $2.50 \times 10$ & earth \\
8 & $0.50 \times 10$ & earth \\
\hline
\end{tabular}

bon in $10 \times 0.75 \times 0.025 \mathrm{~mm}$ was used for the center filament, while three kinds of the sample filament pair were used in the present investigation. These are tungsten ribbons of the same size as the center filament, platinum ribbons in $10 \times 1.20 \times 0.025 \mathrm{~mm}$, and platinized-platinum ribbons in $10 \times 1.20 \times 0.025 \mathrm{~mm}$. The spacing of the filaments was such that each plane of the sample filaments was $3 \mathrm{~mm}$ apart from the center line of the center filament.

The direct current heating was separately applied to the sample filaments connected in parallel, and to the center filament. The determination of filament temperatures during measurements was carried out by setting the filaments of the same size and the same electrical connection in a belljar and measuring filament temperatures at a definite current by means of a newly calibrated optical pyrometer. The calibration due to the emissibility of the filament material was also taken into consideration.

For the ion detection and recording a conventional d.c. amplifier with $1 \times 10^{10} \Omega$ input high resistor (Victreen) and a conventional four elements oscillo-recorder were used. One millimeter deflection on the photographic recording paper by the galvanometer of the highest sensitibity corresponds to $2.7 \times 10^{-14} \mathrm{~A}$. The end vacuum of the instrument prior to each measurement was $1 \times$ $1 \sim 3 \times 10^{-6}$ Torr.

\subsection{Mass Spectrometric Measurements}

Prior to the following measurements, background spectra due to thermal ions emitted from the center filament were recorded, after that the slit system except the filament system was demounted from the ion source and washed with dilute nitric acid solution and re-distilled water and dried by evacuation. Then, using a fine capillary tube, a small amount of the sample solution of the definite concentration was dropped onto the middle parts of two sample filaments and dried by means of a infra-red lamp, and the ion source was remounted and equipped to the apparatus.

Isotope ratio by measured point method. As shown in Fig. 1 ion currents of ${ }^{6} \mathrm{Li}^{+}$and ${ }^{7} \mathrm{Li}^{+}$at a fixed temperature of the center filament and sample filament temperatures $\mathrm{T}_{i}$ were separately plotted in the same figure until nearly exhaustion of them. The ion current ratio $\mathrm{I}\left({ }^{7} \mathrm{Li}^{+}\right) /$ $\mathrm{I}\left({ }^{6} \mathrm{Li}^{+}\right)$, normalized to the time $\mathrm{t}_{i}$ of ${ }^{6} \mathrm{Li}^{+}$measurement was determined and assigned to the lithium isotope ratio for relative measurements by the measured point method.

Isotope ratio by ion current integration method. Ion currents of ${ }^{6} \mathrm{Li}^{+}$and ${ }^{7} \mathrm{Li}^{+}$plotted in the same figure until nearly exhaustion of them were graphically integrated throughout the same range of sample filament temperatures $\mathrm{T}_{i}$ and a fixed temperature of the center filament. The ratio, $\sum_{T_{i}}\left[\int \mathrm{I}\left({ }^{7} \mathrm{Li}^{+}\right) \mathrm{dt}\right] / \sum_{i}\left[\int \mathrm{I}\left({ }^{n} \mathrm{Li}^{+}\right) \mathrm{dt}\right]$ was assigned to the lithium isotope ratio for relative 


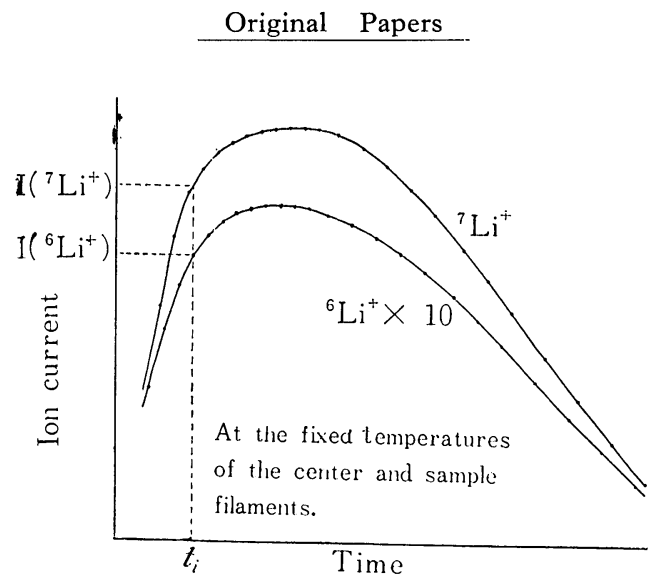

Fig. 2. Measurements of the lithium isotope ratio by the measured point method.

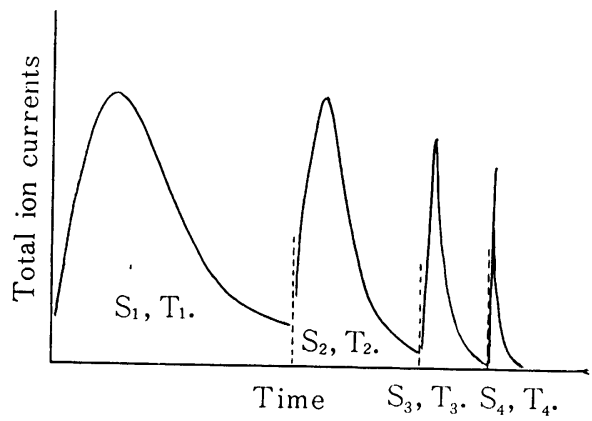

Fig. 3. Variation of the total ion currents with time by successive and stepwise elevation of the sample filament temperature. The center filament temperature was kept in a fixed value.

measurements by the ion current integration method.

Efficiency of sample evaporation. As illustrated in Fig. 3, total ion currents $\mathrm{I}\left(\mathrm{Li}^{+}\right)$of lithium at a fixed temperature of the center filament and sample filament temperatures $T_{i}$ were successively plotted in a same figure until exhaustion,* and the integration of the total currents $\mathrm{S}_{i}=\left[\int \mathrm{I}\left(\mathrm{Li}^{+}\right) \mathrm{dt}\right]_{T_{i}}$ at the sample filament temperature $\mathrm{T}_{i}$ was determined. Then, the efficiency of sample evaporation at the sample filament temperature $\mathrm{T}_{i}$ was obtained by the ratio $\mathrm{S}_{i} / \Sigma \mathrm{S}_{i}$.

Collection efficiency of lithium. The amount of lithium collected in the ion collector was calculated from the summation of the total current integration $\Sigma \mathrm{S}_{i}$ mentioned above. The collection efficiency of sample lithium as the singly charged lithium ions was obtained by the ratio of $\Sigma \mathrm{S}_{i}$ (in gramm) to the amount of sample lithium coated on the sample filaments.

\section{Results and Discussion}

\subsection{Background Spectra}

Main background thermal ions of low mass range from the center filament of tungsten ribbon detected under the present experimental conditions were all singly charged ions of sodium $\left({ }^{23} \mathrm{Na}^{+}\right)$, aluminium $\left({ }^{27} \mathrm{Al}^{+}\right)$, potassium $\left({ }^{39} \mathrm{~K}^{+},{ }^{40} \mathrm{~K}^{+}\right.$and $\left.{ }^{41} \mathrm{~K}^{+}\right)$, calcium $\left({ }^{40} \mathrm{Ca}^{+}\right)$and rubidium $\left({ }^{85} \mathrm{Rb}^{+},{ }^{87} \mathrm{Rb}^{+}\right)$.

* After that the ion currents of ${ }^{6} \mathrm{Li}^{+}$and ${ }^{7} \mathrm{Li}^{+}$at each fixed filament temperature were greatly diminished and the determination of the isotope ratio became practically impossible, the sample filament temperature was stepwisely elevated. 
The background ion currents of lithium $\left({ }^{6} \mathrm{Li}^{+}\right.$and $\left.{ }^{7} \mathrm{Li}^{+}\right)$from the tungsten center filament at the temperature range $900 \sim 2100^{\circ} \mathrm{C}$ were less than the detectable limit (about $1 \times 10^{-14} \mathrm{~A}$ ) of the instrument. The initial relative intensities of main background ions from the tungsten center filament by stepwise heating are summarized in Table 2 .

Table 2. Relative intensities of main background ions from the tungsten center filament in units of $10^{6}$ ions/sec.

\begin{tabular}{c|r|r|r|r|r|r|r}
\hline $\begin{array}{c}\text { Temperature } \\
\text { of the center } \\
\text { filament }\left({ }^{\circ} \mathrm{C}\right)\end{array}$ & \multicolumn{1}{|c}{ Ionic species } \\
\cline { 2 - 8 } & ${ }^{23} \mathrm{Na}^{+}$ & ${ }^{27} \mathrm{Al}^{+}$ & ${ }^{39} \mathrm{~K}^{+}$ & ${ }^{40} \mathrm{Ca}^{+}$ & ${ }^{41} \mathrm{~K}^{+}$ & ${ }^{85} \mathrm{Rb}^{+}$ & ${ }^{87} \mathrm{Rb}^{+}$ \\
\hline 885 & - & - & 600 & - & 43 & - & - \\
1075 & 180 & - & 24000 & - & 1700 & 36 & 14 \\
1210 & 22000 & - & 20000 & - & 1400 & 4 & - \\
1290 & 972 & - & 1400 & - & 100 & - & - \\
1415 & 492 & 320 & 910 & - & 65 & - & - \\
1520 & 132 & 2000 & 700 & 50 & 50 & - & - \\
1650 & 40 & 2 & 84 & 6 & 6 & - & - \\
1735 & 8.4 & - & 23 & - & 2 & - & - \\
1900 & 14 & - & 46 & - & 3 & - & - \\
\hline
\end{tabular}

These background ions emitted from the center filament are characterized as follows: $\mathrm{Na}^{+}$and potassium ions are detectable at above $850^{\circ} \mathrm{C}$ and markedly increase at the temperature range $950^{\circ} \sim 250^{\circ} \mathrm{C}$, but rapidly decrease at temperatures above $2000^{\circ} \mathrm{C}$ by continuous heating for about two hours. The isotope ratios of ${ }^{39} \mathrm{~K} /{ }^{41} \mathrm{~K}$ and ${ }^{85} \mathrm{Rb} /{ }^{87} \mathrm{Rb}$ have resemblance to those usually accepted. ${ }^{27} \mathrm{Al}^{+}$ions appear at above $1400^{\circ} \mathrm{C}$ and considerably increase at about $1500^{\circ} \mathrm{C}$, but rapidly decrease by prolonged heating at this temperature, and they fall below the detectable limit by continuous heating at above $2000^{\circ} \mathrm{C} .{ }^{40} \mathrm{Ca}^{+}$ions in the minor magnitude are detectable at above $1450^{\circ} \mathrm{C}$, but gradually decrease below the detectable limit by continouous heating for two hours at above $2000^{\circ} \mathrm{C}$.

Table 3. Lithium isotope ratios for the laboratory standard lithium sulfate (Merck A.G.). The measurements were carried out under $80 \sim 85 \%$ of the efficiency of sample evaporation.

\begin{tabular}{|c|c|c|c|c|c|c|}
\hline \multirow{2}{*}{$\begin{array}{l}\text { Run } \\
\text { No. }\end{array}$} & \multirow{2}{*}{$\begin{array}{l}\text { Approx. quantity } \\
\text { of } \mathrm{Li} \text { coated } \\
\left(10^{-6} \mathrm{~g}\right)\end{array}$} & \multicolumn{2}{|c|}{$\begin{array}{l}\text { Filament materials } \\
\text { and temp. }\left({ }^{\circ} \mathrm{C}\right)\end{array}$} & \multicolumn{2}{|c|}{ Isotope ratio, ${ }^{7} \mathrm{Li} /{ }^{6} \mathrm{Li}$} & \multirow{2}{*}{$\begin{array}{l}\text { Collect. } \\
\text { effi. } \\
\text { of ions } \\
\left(10^{-6}\right)\end{array}$} \\
\hline & & Sample filaments & Center filment & $\begin{array}{c}\text { Measured point } \\
\text { method }\end{array}$ & $\begin{array}{c}\text { Ion curr. integ. } \\
\text { method }\end{array}$ & \\
\hline I- 1 & 1.9 & w, 1180 & w, 1890 & $12.39 \pm 0.04 *$ & 12.38 & 12 \\
\hline I- 2 & 1.1 & $\mathrm{w}, 1130$ & $\mathrm{w}, 1860$ & $12.37 \pm 0.06$ & 12.36 & 7.6 \\
\hline I- 4 & 1.7 & w, 1140 & $\mathrm{w}, 1650$ & $12.39 \pm 0.03$ & 12.39 & 34 \\
\hline I- 6 & 4.7 & w, 1040 & w, 1630 & $12.40 \pm 0.04$ & 12.39 & 2.1 \\
\hline I- 7 & 2.4 & pt, $\quad 870$ & w, 1670 & $12.39 \pm 0.06$ & 12.34 & 6.0 \\
\hline I- 8 & 1.7 & pt, $\quad 960$ & w, 1710 & $12.38 \pm 0.03$ & 12.40 & 6.1 \\
\hline $\mathrm{I}-10$ & 0.9 & 950 & w, 1710 & $12.37 \pm 0.04$ & 12.39 & 14 \\
\hline $\mathrm{I}-12$ & 2.8 & pt, 980 & w, 1760 & $12.40 \pm 0.06$ & 12.39 & 8.5 \\
\hline $\mathrm{I}-14$ & 1.2 & pt-pt black, 890 & w, 1680 & $12.39 \pm 0.02$ & 12.39 & 7.3 \\
\hline $\mathrm{I}-15$ & 1.9 & pt-pt black, 850 & w, 1650 & $12.39 \pm 0.03$ & 12.40 & 5.1 \\
\hline $\mathrm{I}-17$ & 2.7 & pt-pt black, 910 & w, 1680 & $12.38 \pm 0.02$ & 12.39 & 8.5 \\
\hline
\end{tabular}

* Statistical errors of measurements in the item of the mean deviation.

** Average of the isotope ratios by the ion current integration method and the standard deviation. 
Neither measurable peak of background thermal ions other than ${ }^{23} \mathrm{Na}^{+},{ }^{39} \mathrm{~K}^{+}$and ${ }^{41} \mathrm{~K}^{+}$nor the peak due to the direct surface ionization of lithium sulface was detected for three kinds of the sample filaments at the temperatures listed in Table 3.

\subsection{Lithium Isotope Ratios}

The main results of the lithium isotope ratios obtained for laboratory standard lithium sulfate monohydrate (Merck A.G.) are summarized in Tables 3 and 4. Figs. 4 9 show the typical results

Table 4. Lithium isotope ratios for the laboratory standard lithium sulfate (Merck A.G.) under $90 \sim 95 \%$ of the efficiency of sample evaporation.

\begin{tabular}{|c|c|c|c|c|c|c|}
\hline \multirow{2}{*}{$\begin{array}{l}\text { Run } \\
\text { No. }\end{array}$} & \multirow{2}{*}{$\begin{array}{c}\text { Approx. quantity } \\
\text { of } \mathrm{Li} \text { coated } \\
\left(10^{-6} \mathrm{~g}\right)\end{array}$} & \multicolumn{2}{|c|}{$\begin{array}{l}\text { Filament materials } \\
\text { and temp. }\left({ }^{\circ} \mathrm{C}\right)\end{array}$} & \multicolumn{2}{|c|}{ Isotope ratio, $\mathrm{Li}^{7} / \mathrm{Li}^{6}$} & \multirow{2}{*}{$\begin{array}{l}\text { Collect. } \\
\text { effi. } \\
\text { of ions } \\
\left(10^{-6}\right)\end{array}$} \\
\hline & & Sample filaments & Center filaments & $\begin{array}{c}\text { Measured point } \\
\text { method }\end{array}$ & $\begin{array}{c}\text { Ion curr. integ. } \\
\text { method }\end{array}$ & \\
\hline $\mathrm{I}-20$ & 1.8 & pt, 810 & w, 2020 & $12.39 \pm 0.04 *$ & 12.39 & 2.0 \\
\hline $\mathrm{I}-21$ & 0.7 & pt, 900 & w, 2100 & $12.38 \pm 0.03$ & 12.38 & 11 \\
\hline $\mathrm{I}-24$ & 1.2 & $\mathrm{pt}, \quad 950$ & w, 2100 & $12.37 \pm 0.04$ & 12.37 & 9.3 \\
\hline $\mathrm{I}-25$ & 1.4 & pt, 895 & w, 2100 & $12.38 \pm 0.05$ & 12.40 & 6.4 \\
\hline $\mathrm{I}-26$ & 1.7 & pt, 800 & w, 2100 & $12.36 \pm 0.03$ & 12.38 & 3.5 \\
\hline $\mathrm{I}-29$ & 1.0 & w, 940 & w, 2100 & $12.39 \pm 0.03$ & 12.39 & 11 \\
\hline $\mathrm{I}-30$ & 2.1 & w, 1000 & $\mathrm{w}, 2100$ & $12.37 \pm 0.05$ & 12.39 & 8.6 \\
\hline $\mathrm{I}-32$ & 3.5 & pt-pt black, 780 & w, 2100 & $12.38 \pm 0.02$ & 12.38 & 3.9 \\
\hline
\end{tabular}

* Statistical errors of measurements in the item of the mean deviation.

Average $12.39 \pm 0.01 * *$

** Average of the isotope ratios by the ion current integration method and the standard deviation.

on the distribution of the lithium isotope ratios by the measured point method with time. The sample filaments of platinized-platin ribbon gave the greatest ion currents per $10^{-7} \mathrm{~g}$ of sample lithium at comparable temperatures of the filaments, and this presumably depends upon the fact that the platinizedplatin filaments give the largest surface area and the sample solution uniformly wets these filaments.

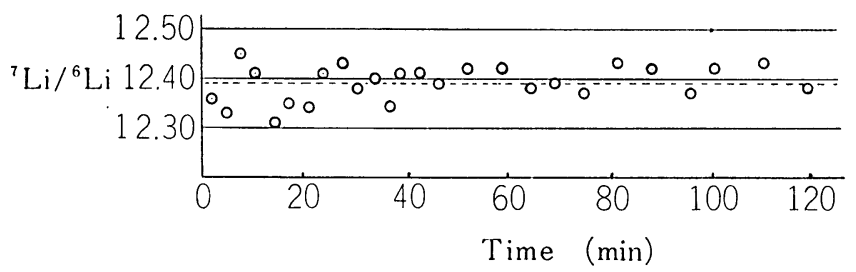

Fig. 4. Distribution of the lithium isotope ratios by the measured point method with time in Run No. 1-4.

$\left({ }^{7} \mathrm{Li} /{ }^{6} \mathrm{Li}\right)_{\text {M.P }}=12.39 \pm 0.03,\left({ }^{7} \mathrm{Li} /{ }^{6} \mathrm{Li}\right)_{\mathrm{I} \cdot \mathrm{I}}=12.39$.

Temp. of the center filament: $1670^{\circ} \mathrm{C}$,

Temp. of the sample filaments: $1140^{\circ} \mathrm{C}$.

The results given in Figs. $4 \sim 6$ and Table 3 were obtained under the experimental conditions in which the efficiency of sample evaporation for each run was about $80 \sim 85 \%$ and the temperatures of the center filament were not high enough. Nevertheless, these results indicate that the isotope fractionation of lithium under evaporation is negligible order of the magnitude since the distribution of the lithium isotope ratios by the measured point method with time is normal and the mean value of them considerably well coincides with the lithium isotope ratio obtained by the ion current integration method. These noticeable tendencies are accomplished again for the results 
S. Taniguchi, O. Toyama and T. Hayakawa: Lithium Isotope Ratio by Surface Ionization I

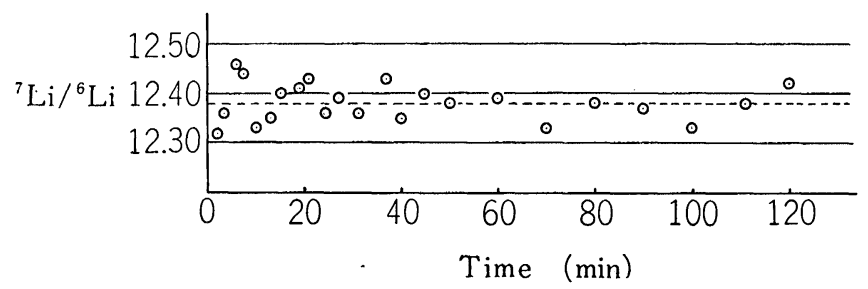

Fig. 5. Distribution of the lithium isotope ratios by the measured point method with time in Run No. 1-8.

$\left({ }^{7} \mathrm{Li} /{ }^{6} \mathrm{Li}\right)_{\mathrm{M} . \mathrm{P}}=12.38 \pm 0.03,\left({ }^{7} \mathrm{Li} /{ }^{6} \mathrm{Li}\right)_{\mathrm{I} . \mathrm{I}}=12.40$.

Temp. of the center filament: $1710^{\circ} \mathrm{C}$,

Temp. of the sample filaments: $960^{\circ} \mathrm{C}$.

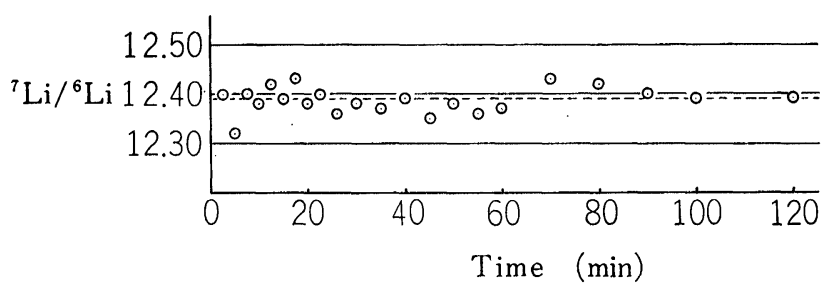

Fig. 6. Distribution of the lithium isotope ratios by the measured point method with time in Run No. 1-15.

$\left({ }^{7} \mathrm{Li} /{ }^{6} \mathrm{Li}\right)_{\mathrm{M} . \mathrm{p}} 12.39 \pm 0.03,\left({ }^{7} \mathrm{Li} /{ }^{6} \mathrm{Li}\right)_{\mathrm{I} . \mathrm{I}}=12.40$.

Temp. of the center filament: $1650^{\circ} \mathrm{C}$,

Temp. of the sample filaments : $850^{\circ} \mathrm{C}$.

given in Figs. $7 \sim 9$ and Table 4 in which the efficiency of sample evaporation was about $90 \sim 95 \%$ and the temperature of the center filament was high enough $\left(2100^{\circ} \mathrm{C}\right)$.

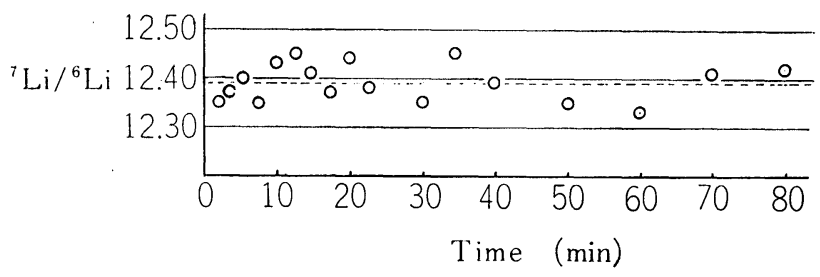

Fig. 7. Distribution of the lithium isotope ratios by the measured point method with time in Run No. 1-20.

$\left({ }^{7} \mathrm{Li} /{ }^{6} \mathrm{Li}\right)_{\text {M.P }}=.12 .39 \pm 0.04,\left({ }^{7} \mathrm{Li} /{ }^{6} \mathrm{Li}\right)_{\text {I.I }}=12.39$.

Temp. of the center filament: $2100^{\circ} \mathrm{C}$,

Temp. of the sample filaments: $810^{\circ} \mathrm{C}$.

Slight discrepancies in the lithium isotope ratios by different methods of measurements shown in Tables 3 and 4 come from the facts that peak height measurements in the initial stage of evaporation inevitably contain considerable errors and that the statistical weights of the measured points are not identical. When the lithium isotope ratios measured in the initial stage of evaporation are discarded, the values of the mean deviations result in smaller than those given in Tables 3 and 4 and the agreements in the lithium isotope ratios between two different methods are fairly improved. 


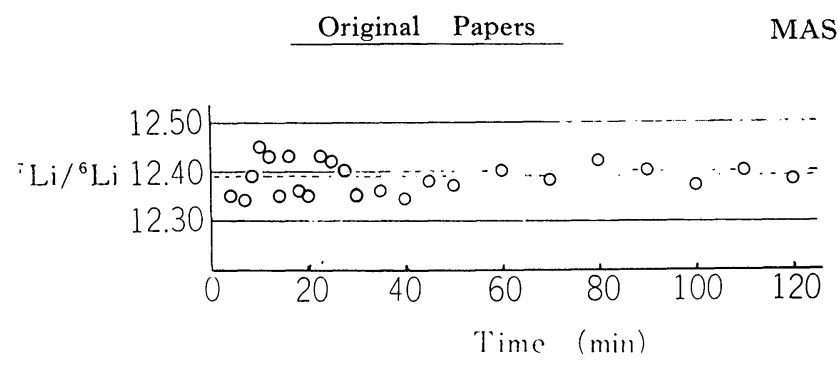

Fig. 8. Distribution of the lithium isotope ratios by the measured point method with time in Run No. 1-29.

$\left({ }^{7} \mathrm{Li} /{ }^{6} \mathrm{Li}\right)_{\text {M. }}=12.39 \pm 0.03,\left({ }^{7} \mathrm{Li} /{ }^{6} \mathrm{Li}\right)_{\text {I.I }}=12.39$.

Temp. of the center filament: $2100^{\circ} \mathrm{C}$,

Temp. of the sample filaments: $940^{\circ} \mathrm{C}$.

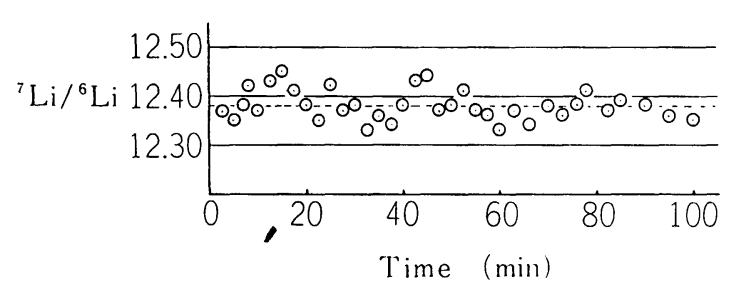

Fig. 9. Distribution of the lithium isotope ratios by the measured point method with time in Run No. 1-32.

$\left({ }^{7} \mathrm{Li} /{ }^{6} \mathrm{Li}\right)_{\mathrm{M} . \mathrm{P}}=12.38 \pm 0.02,\left({ }^{7} \mathrm{Li} /{ }^{6} \mathrm{Li}\right)_{\mathrm{I} . \mathrm{I}}=12.38$

Temp. of the center filament: $2100^{\circ} \mathrm{C}$

Temp. of the sample filaments: $780^{\circ} \mathrm{C}$

It has been observed by some workers in the field of surface ionization that when temperatures of the center filament are not high enough $\left(1900^{\circ} \mathrm{C}\right)$ the ion currents from solid isotopes become unstable and measured isotope ratios result in poor reproducibility. Since this phenomenon mainly arises from the variation in the work function of the center filament caused by surface reactions and contamination, the magnitude of the effect depends not only upon the material and temperatures of the center filament but also upon the va:uim of the ion source region and the molecular structures of evaporated species. For the center filanent of tungsten ribbon and lithium sulfate under investigation, the present authors also observed similar instability of the lithium ion currents due to the appearance of a small and extra maximum of the ion currents at the center filament temperature of about $1150^{\circ} \mathrm{C}$ and variations in the ion currents of this maximum and the succeeding region by intentional lowering of the en 1 vacuum. But, the instability of the lithium ion currents mentioned above never existed for lithium sulfate under investigation in the temperature range of the center filament give in Tables 3 and 4 under ordinary vacuum conditions.

Provided that lithium sulfa:e evaporates from the sample filament surface in the similar manner to free evaporation, the isotope fractionation under evaporation at considerably high temperatures as shown in Tables 3 and 4 is mainly controlled by the square root of the molecular formal wieght ratio of the isotopic molecular species. Since the isotope fractionation under surface ionization is certainly negligible as compared with the isotope fractionation under evaporation, one can expect the approximate factor of $\left({ }^{7} \mathrm{Li}_{2} \mathrm{SO}_{4} /{ }^{6} \mathrm{Li}^{7} \mathrm{LiSO}_{4}\right)^{1 / 2}=1.004$ as the net isotope fractionation in the present measurements. 


\section{No. 21, October. 1962

The provided isotope fractionation mentioned above is rather in minor order of the magnitude, but the effect must result in the slow and systematic shift of the lithium isotope ratio $\left({ }^{7} \mathrm{Li} /{ }^{6} \mathrm{Li}\right)$ with time from lower to higher values. Nevertheless, the results shown in Figs $4 \sim 9$ clearly indicate that there is no measurable systematic shift of the lithium isotope ratio with time, and it is also evident from Tables 3 and 4 that the lithium isotope ratios obtained by the measured point method well coincide with those by the ion current integration method.

According to the results given in Tables 3 and 4 and the discussion mentioned above, the lithium isotope ratio for the laboratory standard lithium sulfate (Merck A.G.) was measured at $12.39 \pm 0.003 *$ by the ion current integration method, while $12.38 \pm 0.01 * *$ was obtained as the lithium isotope ratio by the measured point method. These values are in good agreement to each other within the limits of the statistical errors of measurements.

\subsection{Collection Efficiency of Lithium}

As seen in Tables 3 and 4 , the collection efficiency of lithium under the present experimental conditions is in the order of the magnitude of $10^{-6} \sim 10^{-5}$. Since the collection efficiency of the sample material at the ion collector depends upon the ion source geometry, the potential arrangement of the slit system and the vacuum condition of the analyser tube, more detailed experiments are necessary in order to improve the collection efficiency. The variation of the collection efficiency of lithium given in Tables 3 and 4 may be mainly caused by the poor reproducibility of the filament setting.

\section{Acknowledgements}

The authors wish to express their hearty thanks to Professor H. Hintenberger and his coworkers of Max-Planck-Institut für Chemie in Mainz/Rh. for their helpful advice and discussion. The authors are also indebted to Emelitus Professor N. Sasaki of Kyoto University, Professor T. Titani of Tokyo Metropolitan University and Professor K. Ogata of Osaka University for their constant advice and encouragement. A grant from the Ministry of Education is acknowledged by the third author.

\section{Referances}

1) Hoff Lu, Phys. Rev., 63, 845 (1938).

2) J.R. White and A.E. Cameron, Phys. Rev., 74, 991 (1948).

3) H. Hintenberger, Naturwiss., 34, 52 (1947).

4) A.K. Brewer, J. Chem. Phys., 4, 350 (1936).

5) J. Koch, Z. Physik, 100, 685 (1936).

6) R.F. Hibbs, Natl. Bur. St., Circular, 499, Supplement 1 (1951).

7) K. Ordzhonikidze and V. Shiuttse, J. Exper. Theoret. Phys. USSR, 29, 479 (1955).

8) A.E. Cameron, J. Am. Chem. Soc., 77, 2731 (1955).

9) G.H. Palmer, "Advances in Mass spectrometry (Ed., J.D. Waldron)" Pergamon Press, London (1959), pp. 89.

10) J. Kistemaker, J. Bigeleisen and A.O. Nier, "Proceeding of the International Symposium on Isotope Separation", North-Holland Pub. Co., Amsterdam (1958).

11) A. Klemm and E.U. Monse, Z. Naturforschg., 12a, 319 (1957).

12) S. Taniguchi, I. Shionoya, O. Toyama and T. Hayakawa, Bull. Univ. Osaka Pref., 9a, 59 (1960).

* 0.003 means the standard deviation.

* The standard deviation 0.01 was obtained on the assumption of the identical statistical weight for each measurement. 